\title{
Emerging Changes in Teacher Education
}

\author{
SARAH SMITHERMAN PRATT \\ Independent educator (USA)
}

A difference which makes a difference is an idea.

(Bateson, 1969, p. 272)

The issue is not difference but degree or quality of differencewhether the difference is a difference that makes a difference.

(Doll, 1993, p. 179)

Notions of difference (Bateson, 1969/2000; Deleuze, 1968/1994) and différance (Derrida, 1963) have influenced educational theory for decades, and these ideas continue to play in academic conversations around teaching and learning. Systems theorists have also developed concepts related to difference (e.g., strange attractors, initial seeds, recursion, to name a few). Difference, as Doll (1993) describes, is a quality that will impact thinking and allow for the creation of something new. When new ideas emerge out of conversations, research, and experiences, these ideas are a result of the system of interactions and also fold back into the system to become part of the ongoing conversation.

In complex conversations (Pratt, 2008), difference is interpreted as an opportunity for newness to emerge, recursively playing back into the system to generate ever newer opportunities. Using the concept of complex conversations, I wish to bring forward my own perspective in response to "(Re)Imagining Teacher Preparation for Conjoint Democratic Inquiry in Complex Classroom Ecologies," to create an opportunity for conversation in which something new may emerge out of the system, something that may make a difference.

\section{The System of Teacher Education}

Studies in teacher education continue to show that pre-service teachers learn various theories in universities, but learn "the way it is" in schools. The disconnect between theory and practice 
perpetuates what Britzman's (1991/2003) work showed twenty years ago, that new teachers will begin their career by continuing what they experienced as a student and what they see around them by other teachers who are already in the classroom. In her work as a teacher educator, Britzman recognizes the plight of the pre-service teacher (PST), for "we have all played a role opposite teachers for a large part of our school lives. It is taken for granted that we all know what a teacher is and does. This knowledge is based upon years of observation. It must be remembered that by the time a person enters teacher education, she or he has spent approximately thirteen thousand hours observing teachers" (p. 27). How, then, are teacher educators expected to encourage PSTs to consider a different option, an alternative to what they have lived and experienced as students, or even what they might observe in their field experiences?

In “(Re)Imagining Teacher Preparation for Conjoint Democratic Inquiry in Complex Classroom Ecologies," the authors provide an example of self-actualization through collective interactions, and in their blendings of perspectives from different fields, they embody what they wish teacher education would address - how to "understand our classrooms as complex social collectives" (p. 16) and how to encourage pre-service teachers to become conversants who consider the system of relationships rather than focusing on isolated parts. Their expositions of interpretations of learning and teaching explore the question of why PSTs set out committed to educational equity yet do not sustain in the PK-12 classroom.

The authors begin their article on the common experience of Nora Bateson's movie of her father, Gregory Bateson, and how ideas from the film can be used as a lens to examine their own aspects of teacher preparation. The point on which they focus is the systems perspective that N. Bateson employed in analyzing a therapy session, to recognize that all agents active in a system impact the dynamics within that system. They, too, recognize their roles in the system.

I wish to take this systems perspective and add to the conversation the idea that the dynamics between teacher educators and PSTs, in-service teachers (ISTs) and PSTs, and teacher educators and ISTs continue to be couched in modernist traditions of hierarchical structures. How, instead, can a complex conversation occur among these different roles in a system to foster a difference that makes a difference? How can the conversation steer clear of the mentality that those with experience (ISTs) "know better," while those who have not had such experiences should follow the lead of the "knower"? Or that those who have knowledge of theories (teacher educators) are the "experts" and the novices are those who do not yet understand (Pratt, 2008; Osberg, 2010). How can these three different groups consider ways to embody what Jardine, Clifford \& Friesen (2003) describe as "thinking the world together?"

As a graduate of a teacher education program, an experienced classroom teacher, and a teacher educator, I have played each of these roles. In my current position as teacher educator, I continue to examine power dynamics and hierarchical structures within educational systems. I wish to offer one way in which I have tried to facilitate conversations among teacher educators, in-service teachers, and pre-service teachers. My intention is not to declare that this is "the way" to "solve the problem;" rather, I share my story (Doll, 1993) so that it might inspire other teachers to consider how they can start complex conversations in their own community. What I am sharing is how I believe, as a teacher educator, I have experienced complex conversations as part of a community of learners with PSTs and ISTs. 


\section{Professional Development Schools}

In the report released on November 16, 2010, the National Council for Accreditation of Teacher Education (NCATE) recommends that field experiences must become the primary focus for teacher education. But Wheatley (2010), in his letter to the editor of Education Week, criticizes this recommendation, for "giving in-service teachers more influence over preservice teachers just perpetuates the failed practices in place" (p. 26). How, then, can teacher educators follow the lead of offering more opportunities for field experiences in which PSTs can engage students in learning and be mentored by both a supervising teacher educator and a cooperating classroom teacher, in a way that does not perpetuate what is already in place, that creates opportunities for change for all agents in the system?

Teacher educators actually recognized this issue over 20 years ago and attempted to address it by creating Professional Development Schools (PDS) (Darling-Hammond, 1994; Holmes Group, 1995; Stalling, Wiseman \& Knight, 1991; Winnitzky, Stoddart, O'Keefe, 1992). The premise of this movement was to create collaboration between university and school faculty for changes in teaching and learning, to the benefit of K-12 students and teacher candidates (Kennedy, 1990, p. 5). Many scholars working in a PDS recognize the need for it to be "based on shared respect and joint decision making" (Stallings, Wiseman \& Knight, 1991, p. 134). Darling-Hammond \& McLaughlin (1995) outline policy strategies that need to be in place to support teachers in their changes in teaching and learning, and they state that "professional development today also means providing occasions for teachers to reflect critically on their practice and to fashion new knowledge and beliefs about content, pedagogy, and learners" (p. 598). They believe that there needs to be a shift from attempting to control and direct the work of teachers toward developing responsibility for teaching and learning and supporting development in that regard.

The framework of a PDS is an idea, I argue, that is compatible with systems theory, if it is structured in a way that facilitates community-oriented and collaborative conversations, not hierarchically. I had the privilege of participating in a PDS, and in my own experience, I was part of what I believe, now reflecting back, was a series of complex conversations. In my first year as an assistant professor at a university in the south, I was invited to join a community of educators who were starting a new high school in the local school district. Faculty from the university were included from the beginning in the formation of the new school. We jointly created of the vision and conceptual framework, participated in interviews for faculty, and engaged in conversations among different learning communities (both within and across disciplines) about structures in school, such as policies, schedules, layout, etc.

I began my conversations with the mathematics department chair at these meetings with much fear and trepidation. Mathematics teachers are not exactly known for their willingness to change. Once the school opened, my plan was to just sit and listen, get to know the teachers, and hope that one day they might ask my opinion so I could join the conversation. Much to my surprise, the math chair, Ms. Adams, did not let me sit there for very long. She immediately asked for ideas, suggestions, and thoughts about pedagogical strategies. A 22-year veteran teacher asking for ways to change her methods was quite a surprise, but what an opportunity for me as a teacher educator to work alongside someone to engage students in different teaching methods, to explore concepts rather than memorize and perform mathematics, to 
employ the strategies that I was encouraging my pre-service teachers to utilize even though they had not experienced them in 16 years of mathematics courses nor witnessed such in their own internships.

Ms. Adams acquired her degree, as is typical of secondary mathematics teachers, with a degree in mathematics and a few courses in education. She began her career, in her words, as a "traditional" teacher. While teaching mathematics, she also taught computer science courses. One of her students who was in both of her classes asked her why she was so different, in one class she was engaged, while in the other she just lectured. Realizing that she was teaching computer science from a project-based approach, she began seeking ways to also teach mathematics interactively. She attended a Calculus AP training where she learned some strategies and sought resources that aided her in new ways of teaching. She partnered with the shop teacher to create projects that required knowledge of mathematics and understanding of machines. Ms. Adams continues to use hands-on activities and project-based learning in her teaching today, for she believes in the strength of experience and the depth of understanding that occurs when one actually "sees" it. She has shared some wonderful projects with me that I have incorporated into my own methods courses.

The high school opened its doors in the spring of 2008. In the summer of 2008, I spent time with the math faculty to engage them in activities (not lecture) that would challenge their conceptual understandings of mathematics, using Deborah Ball and Hyman Bass's (2003) Mathematical Knowledge for Teaching framework. After these sessions, I was invited by Ms. Adams to assist her in developing her algebra curriculum that was completely different from the "traditional" way of teaching algebra. She created a course that was designed for the greatest "at-risk" students, and she structured it so that every day she worked with them for a block amount of time to be able to conduct hands-on experiments. Together we created the first two months of activities that would engage the students in numerical understandings (e.g., multiplication and division of whole numbers and integers) so that once algebra was introduced, stronger connections could be made by the students. The fall semester began with a lot of manipulatives and hands-on learning.

Simultaneously, PSTs from the university, enrolled in the secondary mathematics methods course, were placed in classrooms for internships. This is when the fun really began. My primary focus of that course was to have PSTs learn different epistemological interpretations, and how pedagogical strategies should follow the objectives associated with those philosophies. (I rely on Kirshner's (2002) cross-disciplinary strategy for the framework.) I then assigned each PST to interview their mentor teachers about "how a student learns" (asking their epistemology) and to observe their pedagogical strategies. The rationale for this initial task was two-fold: 1) Apply the framework to their data to understand better about epistemologies and pedagogies; and, 2) Have the PST consider the philosophy and pedagogy of their mentor as they are forming their own ideas.

The intern who was placed with Ms. Adams at the PDS high school recognized that her mentor was different from others because she asked a lot of questions from both myself and the intern. She wanted to change her methods. The intern was able to try some new activities she had experienced in the methods course and interpret their effectiveness in conceptual understandings. She reported back to the methods class about how the strategies were working 
or not, how she was adapting what we had done in our course, and how her mentor was suggesting changes. This generated rich conversations in our methods course.

In my role as university supervisor, I am required to perform "observations" of the interns in the classroom. This task looked quite differently when I entered Ms. Adams' classroom. I became a co-teacher alongside the others. I did not just sit in the back and take notes. I joined the conversation, the tag team that they already had in place. I would walk around and assist students while they were engaged in an activity, and I would also lead the whole class in discussions when a moment arose that seemed appropriate (Appelbaum, 2008). (The resource teacher who was assigned to the classroom would also act in the same way, as a true co-teacher, so that all students benefitted from their work together.)

Initially, the high school students seemed confused by this unorthodox approach, but eventually they became comfortable with the fluidity with which different teachers would lead the group. The dynamics were such that if one teacher was not sure how to address a conceptual roadblock, another would prompt by asking a question or jump in and try something different, trying to find a difference that would make a difference. The spirit among the co-teachers and students became that of a learning community rather than a perpetuation of knower/knowee (Pratt, 2008), between teacher educator and IST, IST and PST, and among teachers and students. By the end of the school year, a number of the students who were predicted to not perform well on the state-mandated mathematics exam made significant growth. (Other factors beyond the classroom impacted some of the students' abilities to succeed, but that is beyond the scope of this article.)

In the spring of 2009 the intern was placed with the same mentor teacher for student teaching (a strategy developed by the university faculty for all secondary student teachers). This allowed the intern to continue to co-teach with her mentor, and for me to also participate in my role as supervisor, while she developed her own teacher identity. In her exit interview from the program, she described her experience with her mentor as rewarding and that she felt fully prepared to begin her own classroom. The transition to classroom teacher in the fall of 2009 was quite smooth for her because she felt as if she was already a full-time teacher. Furthermore, her openness to trying new and different activities and her strategies for teaching through hands-on manipulatives rather than merely lecture were incorporated into her daily routine. (In fact, she was awarded the school district's First Year Teacher of the Year Award in mathematics in 2010.)

\section{Do Not Confuse the Map with the Territory}

I share my story as a map for how one IST, one PST and one teacher educator navigated the territory of teacher education and classroom teaching. As Bateson (1980/2002) challenges, however, we must never confuse the map with the territory (p. 118). The territory has many aspects to it; the map that we used should not be translated as a model which then becomes "the" method for conducting teacher education. Rather, this map can serve as an idea, a difference that makes a difference. Thus, by adding my story to this conversation, I am adding my perspective of the territory, offering opportunities for this difference to create a possibly new idea to emerge.

In teacher education, all of us are agents in the system. Just as it is not possible for a teacher to "pour" knowledge into students, it is not reasonable to inspire or encourage a PST to be an 
agent for change without also being the change we wish to see in the system. The time and energy that I have expended in the PDS to develop real relationships with the math faculty is my way of investing in education. If we as teacher educators wish for our PSTs to be able to put into practice the theories that we proffer, we also should be responsible for engaging in the environment in which the internships, student teaching, and full-time teaching occur, not to "fix" the system that is broken but rather to work through our own ideas and to engage in collaboration that is a communal activity, to become part of the system. Relying on a PST to be inspired enough from our teacher education courses to go against the system that is already in place is a modernist ideal. They alone should not be expected to be the agent of change. We are all in this to "think the world together," to strive ways to find differences that will make a difference.

\section{References}

Appelbaum, P., with Allen, D. (2008). Embracing mathematics: On becoming a teacher and changing with mathematics. New York: Routledge.

Ball, D. L., \& Bass, H. (2003). Toward a practice-based theory of mathematical knowledge for teaching. In B. Davis \& E. Simmt (Eds.), Proceedings of the 2002 annual meeting of the Canadian Mathematics Education Study Group (pp. 3-14). Edmonton, Alberta, Canada: Canadian Mathematics Education Study Group (Groupe Canadien d'étude en didactique des mathématiques).

Bateson, G. (1969). Double bind. In G. Bateson (2000), Steps to an ecology of mind (pp. 271-278). Chicago, IL: University of Chicago Press. (Original work published 1972)

Bateson, G. (2002). Mind and nature: A necessary unity (5 ${ }^{\text {th }}$ ed.). Cresskill, NJ: Hampton Press. (Original work published 1980)

Darling-Hammond, L. (Ed.) (1994). Professional development schools: Schools for developing a profession. Teachers College Press: New York.

Darling-Hammond, L. \& Mclaughlin, M. (1995). Policies that support professional development in an era of reform. Phi Delta Kappan, 76 (8), 597-604.

Deleuze, G. (1994). Difference and repetition. (Paul Patton, Trans.). New York: Columbia University Press. (Original work published 1968)

Derrida, J. (1982). Différance. In J. Derrida (Ed.), Margins of philosophy (pp. 3-27). (Alan Bass, Trans.). Chicago, IL: Chicago University Press.

Doll, W. (1993). A post-modern perspective on curriculum. New York: Teachers College.

Holmes Group. (1995). Tomorrow's schools of education: A report of the Holmes Group. The Holmes Group: East Lansing, MI.

Jardine, D., Clifford, P., \& Friesen, S. (2003). Back to the basics of teaching and learning: Thinking the world together. Mahwah, NJ: Lawrence Erlbaum.

Kennedy, M. (1990). On the development of professional development schools: An interview with Charles Thompson. NCRTE Colloquy, 3 (2), 5-13.

Kirshner, D. (2002). Untangling teachers' diverse aspirations for student learning: A Crossdisciplinary strategy for relating psychological theory to pedagogical practice. Journal for Research in Mathematics Education, 33 (1), 46-58.

National Council for Accreditation of Teacher Education (NCATE). (November 16, 2010). Press Release: Panel calls for turning teacher education 'upside down,' centering curricula around classroom-ready training and increasing oversight and expectations. Retrieved online January 20, 2010 http://www.ncate.org/Public/Newsroom/NCATENewsPressReleases/tabid/669/EntryId/125/Panel-callsfor-turning-teacher-education-upside-down-centering-curricula-around-classroom-ready-training-andincreasing-oversight-and-expectations.aspx.

Osberg, D. (2010). Knowledge is not made for understanding; it is made for cutting. Complicity, 7 (2), pp. iii-viii. 
Stallings, Wiseman and Knight, S. (1991). Professional development schools: A New generation of schooluniversity partnerships. In H. Petrie (Ed.), Professionalization, partnership, and power: Building professional (pp. 133-144). SUNY Press.

Wheatley, G. (2010). More preservice teaching in schools not effective (Letter to the Editor). Education Week, 30 (14), p. 26. Retrieved online January 4: http://www.edweek.org/ew/articles/2010/12/08/14letter1.h30.html?r=1737546376.

Winnitzky, N., Stoddart, T., O'Keefe, P. (1992). Great expectations: Emergent professional development schools. Journal of Teacher Education, 43 (1), 3-18.

\section{About the Author}

Sarah Smitherman Pratt is the 2011 President-Elect of the AERA SIG: Chaos and Complexity Theories. Currently her chief research interests include exploring complex conversations in teacher education and examining pre-service and in-service teachers' conceptual understandings of mathematics. She currently resides in Baton Rouge, Louisiana with her husband and two daughters.

(C) Copyright 2011. The author, Sarah Smitherman Pratt, assigns to the University of Alberta and other educational and non-profit institutions a non-exclusive license to use this document for personal use and in courses of instruction provided that the article is used in full and this copyright statement is reproduced. The author also grants a non-exclusive license to the University of Alberta to publish this document in full on the World Wide Web, and for the document to be published on mirrors on the World Wide Web. Any other usage is prohibited without the express permission of the authors. 